\title{
Od monoklonalnej gammapatii o nieokreślonym znaczeniu (MGUS) do szpiczaka plazmocytowego i amyloidozy - opis przypadku
}

\author{
From monoclonal gammapathy of undetermined significance \\ (MGUS) to plasma cell myeloma and amyloidosis - a case report
}

\author{
Michał Bator, Stanisław Potoczek, Lidia Usnarska-Zubkiewicz \\ Katedra i Klinika Hematologii, Nowotworów Krwi i Transplantacji Szpiku, Uniwersytet Medyczny we Wrocławiu
}

\begin{abstract}
Streszczenie
Przedstawiono 69-letnia pacjentke, u której w marcu 2016 roku stwierdzono monoklonalna gammapatie o nieokreślonym znaczeniu (MGUS). Chorobę rozpoznano w czasie diagnostyki wystęujacej od 2009 roku matoptytkowości (liczba plytek krwi 90-140 G/l). W immunofikasacji surowicy stwierdzono obecność biatka monoklonalnego IgG kappa. W lipcu 2017 roku u chorej stwierdzono zespót nerczycowy i ostrq niewydolność nerek, a w szpiku - 14,5\% plazmocytów. Biopsja tkanki ttuszczowej z fatdu brzusznego wykazata obecność amyloidu z tańcuchów lekkich kappa. Rozpoznano szpiczaka plazmocytowego (PCM) IgG kappa powiktanego amyloidoza nerek, serca, watroby oraz śledziony. Przebieg PCM powiktanego amyloidoza byt bardzo agresywny; mimo zastosowanego leczenia bortezomibem $i$ deksametazonem chora szybko zmarta. Nagte pogorszenie sie stanu zdrowia (np. w postaci ostrej niewydolności nerek) u chorego na MGUS może wskazywać nie tylko na progresje MGUS do PCM, ale także rozwój amyloidozy, co wiaże sie z burzliwym przebiegiem choroby $i$ ztym rokowaniem.
\end{abstract}

Słowa kluczowe: MGUS, szpiczak plazmocytowy, amyloidoza

Hematologia 2018; 9, 4: 336-341

\begin{abstract}
We present a 69-year-old patient, in whom in March 2016 a monoclonal gammopathy of undetermined significance (MGUS) was diagnosed. The disease was found during the diagnostics of thrombocytopenia (from 2009 the number of platelets varied between 90-140 G/l). In serum immunofixation assay the presence of monoclonal IgG kappa protein was confirmed. In July 2017, when the patient presented with nephrotic syndrome and acute renal failure, $14.5 \%$ of plasma cells were found in the bone marrow. Moreover, a biopsy of abdominal fat revealed the presence of amyloid composed of kappa light chains. The diagnosis of IgG kappa plasma cell myeloma (PCM) complicated with amyloidosis of the kidneys, heart, liver and spleen was established. The PCM progression complicated with amyloidosis was very aggressive. Despite the treatment with bortezomib and dexamethasone the patient died early. Sudden deterioration of health (e.g. in the form of acute
\end{abstract}

Adres do korespondencji: Lidia Usnarska-Zubkiewicz, Katedra i Klinika Hematologii, Nowotworów Krwi i Transplantacji Szpiku, Uniwersytet Medyczny we Wrocławiu, ul. Wybrzeże Pasteura 4, 50-36 Wrocław, e-mail: lidia.usnarska-zubkiewicz@umed.wroc.pl 


\begin{abstract}
renal failure) in a patient with MGUS may indicate not only the progression of MGUS to PCM, but also the development of amyloidosis, which is associated with turbulent disease and poor prognosis.
\end{abstract}

Key words: MGUS, plasma cell myeloma, amyloidosis

Hematologia 2018; 9, 4: 336-341

\section{Wprowadzenie}

Karl von Rokitansky, austriacki lekarz czeskiego pochodzenia, profesor Uniwersytetu w Wiedniu, w 1842 roku opisał chorobę, w przebiegu której w chorobowo zmienionych tkankach występowały złogi substancji reagującej podobnie do skrobii (łac. amylum — skrobia) $\mathrm{w}$ reakcji barwienia $\mathrm{z}$ jodyną i kwasem siarkowym. Na podstawie tych właśnie podobieństw niemiecki antropolog i patolog Rudolf Virchow nadał nowej chorobie nazwę skrobiawica, amyloidoza [1-3].

Amyloidoza nie jest pojedynczą jednostką chorobową; tworzy szeroką niejednorodną grupę chorób, u podłoża których leży odkładanie się (głównie zewnątrzkomórkowo) autologicznych białek o nieprawidłowej konformacji w formie beta-kartki. Gromadzenie tych drugorzędowych struktur białkowych prowadzi do postępującego zaburzenia funkcjonowania narządów $[4,5]$. Odkładanie się patologicznej formy białka może zachodzić $\mathrm{w}$ formie ograniczonej do tkanki lub narządu, ale może mieć również charakter układowy.

Podstawami nowoczesnych metod klasyfikacji amyloidozy są właściwości i charakterystyka białek prekursorowych, które tworzą złogi włóknikowe. Obecnie znanych jest około 30 różnych typów amyloidozy [6]. Inni autorzy sugerują występowanie ponad 60 różnych białek, które mogą tworzyć włókienkowe formy amyloidowe [7]. Do najczęściej występujących typów amyloidozy zalicza się układową amyloidozę łańcuchów lekkich (amyloidoza $\mathrm{AL}$, light-chain amyloidosis, dawniej nazywaną amyloidozą pierwotną), reaktywną amyloidozę układową (dawniej nazywaną amyloidozą wtórną), która stanowi powikłanie przewlekłych chorób reumatycznych, szczególnie reumatoidalnego zapalenia stawów, idiopatycznego młodzieńczego zapalenia stawów oraz innych zespołów autoimmunizacyjnych, oraz amyloidozę dziedziczną (wrodzoną) typu ATTR (w przypadku której zachodzi mutacja $\mathrm{w}$ genie kodującym białko transtyretynę) [8-10]. W układowej amyloidozie AL włókienka amyloidu są utworzone $z$ lańcuchów lekkich immunoglobulin kappa lub lambda syntetyzowanych przez klonalną populację komórek plazmatycznych szpiku kostnego [10, 11]. Patologiczne białka mogą uszkodzić praktycznie każdy narząd, najczęściej zajęte są serce i nerki. Amyloidowe uszkodzenie serca przebiega zwykle pod postacią niewydolności mięśnia sercowego, a uszkodzenie nerek często objawia się zespołem nerczycowym i postępującym pogorszeniem funkcji narządu.

Według aktualnych danych szacuje się, że w Stanach Zjednoczonych żyje około 12 tys. dorosłych chorych na amyloidozę AL, a liczba ta w najbliższych latach najprawdopodobniej się zwiększy [12]. Corocznie w Stanach Zjednoczonych notuje się 1275-3200 nowych przypadków amyloidozy AL [13]. Według danych literaturowych częstość występowania amyloidozy ocenia się na 3-12 chorych/mln osób/rok; sumaryczną liczbę chorych cierpiących na amyloidozę AL w Stanach Zjednoczonych i Unii Europejskiej szacuje się na 30-45 tys. pacjentów [14-16]. Amyloidoza jest najczęściej rozpoznawana po 60 . roku życia, mediana wieku w chwili rozpoznania wynosi 64 lata [17].

$\mathrm{W}$ artykule przedstawiono przypadek pacjentki, u której po ponad roku od rozpoznania monoklonalnej gammapatii o nieokreślonym znaczeniu (MGUS, monoclonal gammapathy of undetermined significance) rozpoznano szpiczaka plazmocytowego (PCM, plasma cell myeloma) powikłanego amyloidozą AL o bardzo agresywnym przebiegu.

\section{Opis przypadku}

Pacjentka w wieku 67 lat, dotychczas nielecząca się przewlekle, w marcu 2016 roku została przyjęta do kliniki chorób infekcyjnych i alergologii w celu przeprowadzenia diagnostyki małopłytkowości (liczba płytek krwi wahała się od 90 do 149 G/ /1) występującej w badaniach laboratoryjnych od 2009 roku. Pacjentka zgłaszała występujące okresowo sztywność i bolesność stawów międzypaliczkowych rąk, skłonność do występowania nieuzasadnionych podbiegnięć krwawych na skórze oraz występowanie samoistnych krwawien $z$ nosa. $Z$ powodu niecharakterystycznych objawów wykonano liczne badania laboratoryjne, które nie wykazały obecności przeciwciał przeciwjądrowych (ANA, antinuclear antibody), przeciwciał przeciwko mięśniom gładkim (ASMA, anti-smooth muscle antibodies) ani przeciwciał przeciwmitochondrialnych 
(AMA, antimitochondrial antibodies). Wyniki testów w kierunku wątrobowo-nerkowych przeciwciał przeciwmikrosomalnych anty-LKM i przeciwciał anty-HBC również były ujemne. Immunofiksacja białek surowicy wykazała obecność komponenty monoklonalnej IgG kappa. Stwierdzono ponadto zwiększone stężenie białka całkowitego $8,9 \mathrm{~g} / \mathrm{dl}$, immunoglobulin G (IgG) $2630 \mathrm{mg} / \mathrm{dl}$, leukopenię - liczba krwinek białych (WBC, white blood count) $2,99 \mathrm{G} / 1$ oraz hipertransaminazemię - aminotransferaza alaninowa (AlAT, alanine aminotransferase) $61 \mathrm{j} . / 1$, aminotransferaza asparaginianowa (AspAT, aspartate aminotransferase) $72 \mathrm{j} . / 1$. W mielogramie stwierdzono 5,6\% plazmocytów. Pacjentkę $z$ rozpoznaniem MGUS skierowano do poradni hematologicznej.

25 lipca 2017 roku chora została przyjęta na oddział nefrologiczny $z$ powodu ostrej niewydolności nerek, a następnie przekazana do Kliniki Hematologii, Nowotworów Krwi i Transplantacji Szpiku Uniwersytetu Medycznego we Wrocławiu. W wywiadzie podawała postępujące osłabienie i znaczną utratę masy ciała w ciągu ostatnich 2 miesięcy. W badaniu przedmiotowym zwracały uwage liczne podbiegnięcia krwawe, powiększenie wątroby, cechy niewydolności prawokomorowej serca, niskie ciśnienie tętnicze $(100 / 65 \mathrm{~mm} \mathrm{Hg})$. Badania laboratoryjne wykazały niedokrwistość (stężenie hemoglobiny [Hb] 9,7 g/dl), małopłytkowość (49 G/l), zwiększone stężenie kreatyniny w surowicy 2,91 $\mathrm{mg} / \mathrm{dl}$ ze współczynnikiem przesączania kłębuszkowego (GFR, glomerular filtration rate) $16,9 \mathrm{ml} /$ /min, zwiększone stężenie bilirubiny całkowitej $1,8 \mathrm{mg} / \mathrm{dl}$, zmniejszone stężenie albumin $2,5 \mathrm{~g} / \mathrm{dl}$ oraz zwiększoną aktywność enzymów wątrobowych, zwłaszcza gammaglutamylotranspeptydazy (GGTP, gamma-glutamyl transferase) - 411 j./l. Stężenie wolnych łańcuchów lekkich w surowicy (sFLC, serum free light chains) kappa wynosito $18500 \mathrm{mg} / \mathrm{dl}$. Ponadto stwierdzono liczne zaburzenia krzepnięcia osoczowego, tj. obecność antykoagulanta toczniowego, obniżone stężenia czynników IX, X, XI oraz XII. W badaniu ultrasonograficznym (USG) wykazano powiększoną wątrobę (w linii środkowo-obojczykowej wielkości $146 \mathrm{~mm}$ ) z cechami włóknienia. Poza tym w obu płatach wątroby uwidoczniono obecność pojedynczych, policyklicznych ognisk hiperechogennych wielkości do $10 \mathrm{~mm}$, które mogły odpowiadać amyloidozie miąższu wątroby. W badaniu USG nerek zobrazowano niemal zatarte zróżnicowanie korowo-rdzeniowe, co radiologicznie mogło wskazywać na zmiany w przebiegu amyloidozy. W USG śledziona okazała się powiększona, w wymiarze dwubiegunowym
$192 \mathrm{~mm}$. W gastroskopii uwidoczniono zapalenie błony śluzowej żołądka i dwunastnicy. Z kolei w mielogramie stwierdzono $14,5 \%$ plazmocytów w szpiku, a w biopsji cienkoigłowej tkanki tłuszczowej $z$ fałdu brzusznego - obecność amyloidu. $\mathrm{U}$ chorej zdiagnozowano również liczne zmiany osteolityczne kości czaszki, kręgosłupa (C4, Th12, L2), kości biodrowych, lewej kości udowej oraz wieloodłamowe złamanie prawego obojczyka. Na podstawie całokształtu obrazu klinicznego rozpoznano PCM IgG kappa powikłanego amyloidozą AL $z$ prawdopodobnym zajęciem serca, nerek, śledziony oraz wątroby. Za rozpoznaniem amyloidozy serca przemawiała niewydolność krążenia $z$ wysokim stężeniem peptydu natriuretycznego typu B (BNP, B-type natriuretic peptide) osiągającym maksymalną wartość $1285 \mathrm{pg} / \mathrm{ml}$. W trakcie hospitalizacji obserwowano napady migotania przedsionków z szybką czynnością komór serca. Zastosowano umiarawiające leczenie farmakologiczne (amiodaron) $z$ dobrym efektem.

$\mathrm{Na}$ zajęcie nerek w przebiegu amyloidozy wskazywały ich obraz ultrasonograficzny, obecność zespolu nerczycowego i ostry charakter niewydolności. Przyjęto, że zwiększone stężenie bilirubiny, większa aktywność enzymów wątrobowych, liczne zaburzenia białkowe, w tym zaburzenia w osoczowym układzie krzepnięcia, są wynikiem amyloidozy wątroby, za czym przemawiał również obraz ultrasonograficzny tego narządu. Ze względu na postępujące pogarszanie się stanu ogólnego pacjentki nie wykonano biopsji nerek i wątroby.

W terapii zastosowano leczenie bortezomibem i deksametazonem. Bortezomib podawano w dniach 1., 4., 8. i 11. cyklu w dawce $1,3 \mathrm{mg} / \mathrm{m}^{2}$ - uwzględniając powierzchnię ciała pacjentki, przyjmowała ona $2,14 \mathrm{mg}$, natomiast deksametazon podawano $\mathrm{w}$ dniach 1.-4. oraz w dniach 9.-12, w dawce $20 \mathrm{mg}$. Mimo zastosowanego leczenia narastały niewydolność nerek i hiperkalcemia, pacjentka była dializowana. Przez cały okres pobytu stosowano leczenie przeciwkrwotoczne (przetoczenia koncentratów krwinek płytkowych i świeżo mrożonego osocza) oraz substytuowano masę erytrocytarną. Mimo intensywnego leczenia nie udało się uzyskać poprawy stanu chorej - zmarła po 22 dniach pobytu w klinice. Przyczyną była niewydolność wielonarządowa. Do momentu zgonu pacjentka przyjęła 4 dawki bortezomibu oraz 8 dawek deksametazonu.

\section{Dyskusja}

Pogorszenie czynności narządów (najczęściej nerek i serca), postępujące zmęczenie, wynisz- 
czenie, osłabienie, pogorszenie ogólnego stanu zdrowia bez uchwytnej przyczyny, obrzęki, zmiana rytmu wypróżnień czy zaburzenia neurologiczne u chorego $z$ MGUS powinny budzić podejrzenie amyloidozy. Do bardziej charakterystycznych objawów amyloidozy AL należą uszkodzenie nerek (prowadzące do białkomoczu i zespołu nerczycowego oraz postępującej niewydolności nerek), dystrofia paznokci, hipotonia ortostatyczna oraz zespół cieśni nadgarstka. Najbardziej charakterystyczne objawy amyloidozy to występujące u 10-25\% pacjentów powiększenie języka i obecne u 12\% podbiegnięcia krwawe wokół oczu [18]. Obraz kliniczny amyloidozy AL w przebiegu PCM i bez potwierdzenia szpiczaka jest podobny [19, 20].

U zaprezentowanej chorej rozwój szpiczaka powikłanego amyloidozą był poprzedzony występowaniem MGUS. Transformacja MGUS do PCM występuje u $1-2 \%$ osób rocznie, uważa się natomiast, że prawie wszystkie przypadki szpiczaka są poprzedzone MGUS [21, 22]. Jednak, mając na uwadze zwykle wieloletni przebieg amyloidozy, warto zaznaczyć, że pacjentka mogła chorować na nią już w czasie zdiagnozowania MGUS, a również nie można wykluczyć, że choroba występowała dużo wcześniej przed rozpoznaniem MGUS. Ze względu na nieobecność charakterystycznych objawów amyloidoza nie stanowiła istotnego punktu podczas diagnostyki różnicowej. Trzeba jednak podkreślić, że pacjenci z MGUS lub chorujący na PCM wymagają szczególnej obserwacji pod względem pojawienia się u nich niecharakterystycznych objawów (takich jak niewydolność serca, obrzęki, neuropatia, zmienny rytm wypróżnień, plamica czy hipotonia ortostatyczna). Do ostatecznego rozpoznania amyloidozy AL konieczne jest wykonanie biopsji tkankowej. W takiej sytuacji najczęściej jest to biopsja tkanki tłuszczowej, ale niestety czułość tej metody w rozpoznawaniu amyloidozy AL wynosi tylko około 75\%. Dlatego zaleca się również przeprowadzenie równoczesnego badania histopatologicznego szpiku $\mathrm{z}$ barwieniem czerwienią Kongo. Jeżeli zarówno wynik badania bioptatu pobranego $z$ tkanki tluszczowej, jak i wynik badania histopatologicznego szpiku na obecność amyloidu są negatywne, a u pacjenta stwierdza się wysokie prawdopodobieństwo występowania amyloidozy, to należy rozważyć wykonanie biopsji zajętego narządu. Do badań pomocniczych w diagnostyce amyloidozy AL należy również pomiar stężenia N-końcowego fragmentu propeptydu natriuretycznego typu B (NT-proBNP, $N$-terminal pro-B-type natriuretic peptide) lub BNP. W diagnostyce oraz ocenie klinicznej ważną rolę pełni również ocena stężenia troponiny T. Badaniem ogólnodostępnym i nieinwazyjnym jest USG serca, ponieważ obraz serca obserwowany u chorych na amyloidozę jest dość typowy.

Warto podkreślić, że w czasie obserwacji ambulatoryjnej $\mathrm{u}$ chorej nie były obecne objawy amyloidozy, w wywiadzie podawała dobre samopoczucie, a w badaniu przedmiotowym nie obserwowano typowych zmian charakterystycznych dla amyloidozy AL. Wyniki badań laboratoryjnych, poza obecnością białka monoklonalnego, były prawidłowe. Ostatnie prawidłowe wyniki badań, w tym stężenie $\mathrm{Hb}$, parametry funkcji nerek, wartości enzymów wątrobowych i parametry układu krzepnięcia, odnotowano w marcu 2017 roku. Wystąpienie ostrej niewydolności nerek wskazywało na progresję MGUS. U chorej rozpoznano PCM i jednocześnie amyloidozę AL.

Głównym niekorzystnym czynnikiem rokowniczym w przebiegu amyloidozy jest zajęcie serca, które najczęściej występuje w amyloidozie AL i amyloidozie ATTR, za czym przemawia pogrubienie jego ścian $z$ jednoczesnym ograniczeniem zdolności skurczowej [23, 24]. U pacjentki w czasie obserwacji ambulatoryjnej nie występowały objawy charakterystyczne dla amyloidowych zmian mięśnia sercowego, w tym objawy prawokomorowej niewydolności serca (należy pamiętać, że pozakomórkowe odkładanie amyloidu zachodzi w obrębie całego mięśnia sercowego), a brak objawów, takich jak wodobrzusze, podwyższone ciśnienie w żyłach szyjnych, osłabienie, obrzęki obwodowe lub obniżenie ciśnienia tętniczego (ciśnienie skurczowe $<100 \mathrm{~mm} \mathrm{Hg}$ ), utrudniały wcześniejsze postawienie diagnozy. W czasie pobytu w klinice u chorej zaobserwowano objawy niewydolności prawokomorowej, w badaniu USG serca stwierdzono powiększenie wymiarów lewego przedsionka $\mathrm{w}$ rozkurczu, a ponadto u pacjentki występowały epizody migotania przedsionków, co stwierdza się dość często, bo w 10-15\% przypadków amyloidozy serca [24]. W badaniach klinicznych Rapezzie'go i wsp. [25] wykazano brak korelacji między liczbą włókien amyloidowych obecnych w mięśniu sercowym i stopniem jego uszkodzenia, a co za tym idzie - średnią długością przeżycia pacjentów. Warto jednak zaznaczyć, że to właśnie obecność włókien amyloidowych w sercu ma kluczowy i najważniejszy wpływ zarówno na rokowanie pacjenta, jak i na wybór najlepszej metody terapii.

Trwają intensywne prace nad zrozumieniem patomechanizmu uszkodzenia miokardium zachodzącego podczas procesu amyloidogenezy. Zrozumienie tych procesów na pewno spowoduje 
nowe medyczne implikacje w postaci indywidualnie dobranej terapii celowanej. Istnieją dowody na rolę aktywowanej mitogenem kinazy białkowej (MAPK, mitogen-activated protein kinase) p38 w patomechanizmie stresu oksydacyjnego, który jest zaangażowany $\mathrm{w}$ proces uszkodzenia serca u pacjentów $z$ amyloidozą AL [26]. Grupę MAPK tworzy kilka klas kinaz, których aktywacja skutkuje wzrostem proliferacji, różnicowania, apoptozy czy nasileniem procesów zapalnych komórki. Dowiedziono, że leczenie za pomocą SB203580, selektywnego inhibitora p38 MAPK, znacząco osłabia stres oksydacyjny, zmniejsza dysfunkcję komórek i apoptozę. Być może w przyszłości inhibitory te znajdą większe zastosowanie kliniczne w leczeniu między innymi amyloidozy serca [27, 28].

\section{Podsumowanie}

Terminem amyloidoza określa się grupę chorób spichrzeniowych, w przebiegu których dochodzi do gromadzenia się, głównie w przestrzeni pozakomórkowej różnych tkanek, patologicznej, amorficznej substancji, która powstaje na skutek nieprawidłowego metabolizmu białek i jest oporna na proteolizę, co prowadzi do zniszczenia prawidłowej architektoniki tkanek i upośledzenia ich funkcji. Odkładanie się patologicznego białka może przyjmować wiele postaci, a obraz kliniczny często się nakłada na inne obecne schorzenia.

$\mathrm{W}$ prezentowanym przypadku przebieg szpiczaka powikłanego amyloidozą AL, który rozwinął się u osoby obserwowanej z powodu MGUS, był niezwykle agresywny. Nagłe pogorszenie się stanu zdrowia (np. w postaci ostrej niewydolności nerek) u chorego na MGUS może wskazywać nie tylko na progresję MGUS do PCM, ale także rozwój amyloidozy, co wiąże się $z$ burzliwym przebiegiem choroby i złym rokowaniem.

\section{Piśmiennictwo}

1. Gertz MA, Kyle RA. Primary systemic amyloidosis - a diagnostic primer. Mayo Clin Proc. 1989; 64(12): 1505-1519, indexed in Pubmed: 2513459.

2. Alaani A, Warfield AT, Pracy JP. Management of laryngeal amyloidosis. J Laryngol Otol. 2004; 118(4): 279-283, doi: 10.1258/0022 21504323012021, indexed in Pubmed: 15117466.

3. Titford M. Rudolf Virchow: cellular pathologist. Lab Med. 2010; 41(5): 311-312, doi: 10.1309/lm3gyqty79cpylbi.

4. Cunnane G. Amyloid proteins in pathogenesis of AA amyloidosis. Lancet. 2001;358(9275): 4-5, doi: 10.1016/S0140-6736(00)05297-1, indexed in Pubmed: 11454365.

5. Dobson CM. Protein aggregation and its consequences for human disease. Protein Pept Lett. 2006; 13(3): 219-227, indexed in Pubmed: 16515449.
6. Sipe JD, Benson MD, Buxbaum JN, et al. Nomenclature 2014: amyloid fibril proteins and clinical classification of the amyloidosis. Amyloid. 2014; 21(4): 221-224, doi: 10.3109/13506129.2014. 964858, indexed in Pubmed: 25263598.

7. Mok KH, Pettersson J, Orrenius S, et al. HAMLET, protein folding, and tumor cell death. Biochem Biophys Res Commun. 2007; 354(1): 1-7, doi: 10.1016/j.bbrc.2006.12.167, indexed in Pubmed: 17223074.

8. Obici L, Raimondi S, Lavatelli F, et al. Susceptibility to AA amyloidosis in rheumatic diseases: a critical overview. Arthritis Rheum. 2009; 61(10): 1435-1440, doi: 10.1002/art.24735, indexed in Pubmed: 19790131.

9. Falk RH. Diagnosis and management of the cardiac amyloidoses. Circulation. 2005; 112(13): 2047-2060, doi: 10.1161/CIRCULATIONAHA.104.489187, indexed in Pubmed: 16186440.

10. Sanchorawala V. Light-chain (AL) amyloidosis: diagnosis and treatment. Clin J Am Soc Nephrol. 2006; 1(6): 1331-1341, doi: 10.2215/CJN.02740806, indexed in Pubmed: 17699366.

11. Rosenzweig M, Landau H. Light chain (AL) amyloidosis: update on diagnosis and management. J Hematol Oncol. 2011; 4: 47, doi: 10.1186/1756-8722-4-47, indexed in Pubmed: 22100031.

12. Quock TP, Yan T, Chang E, et al. Epidemiology of AL amyloidosis: a real-world study using US claims data. Blood Adv. 2018; 2(10): 1046-1053, doi: 10.1182/bloodadvances.2018016402, indexed in Pubmed: 29748430.

13. Falk RH, Comenzo RL, Skinner M. The systemic amyloidoses. N Engl J Med. 1997; 337(13): 898-909, doi: 10.1056/ /NEJM199709253371306, indexed in Pubmed: 9302305.

14. Desport E, Bridoux F, Sirac C, et al. Centre National de Référence pour l'Amylose AL et les Autres Maladies par Dépôts d'Immunoglobulines Monoclonales. Al amyloidosis. Orphanet J Rare Dis. 2012; 7: 54, doi: 10.1186/1750-1172-7-54, indexed in Pubmed: 22909024.

15. Pinney JH, Smith CJ, Taube JB, et al. Systemic amyloidosis in England: an epidemiological study. Br J Haematol. 2013; 161(4): 525-532, doi: 10.1111/bjh.12286, indexed in Pubmed: 23480608.

16. Lin HM, Gao X, Cooke CE, et al. Disease burden of systemic light-chain amyloidosis: a systematic literature review. Curr Med Res Opin. 2017; 33(6): 1017-1031, doi: 10.1080/03007995.2017.1 297930, indexed in Pubmed: 28277869.

17. Ebert EC, Nagar M. Gastrointestinal manifestations of amyloidosis. Am J Gastroenterol. 2008; 103(3): 776-787, doi: 10.1111/j.1572-0241.2007.01669.x, indexed in Pubmed: 18076735.

18. Dubrey SW, Cha K, Anderson J, et al. The clinical features of immunoglobulin light-chain (AL) amyloidosis with heart involvement. QJM. 1998; 91(2): 141-157, indexed in Pubmed: 9578896.

19. Usnarska-Zubkiewicz L, Hołojda J, Jeleń M, et al. The occurrence of $\mathrm{Al}$ amyloidosis (light-chain amyloidosis) in patients with multiple myeloma in Lower Silesia Region, Poland. Adv Clin Exp Med. 2014; 23(2): 235-244, indexed in Pubmed: 24913114.

20. Madan S, Dispenzieri A, Lacy MQ, et al. Clinical features and treatment response of light chain $(\mathrm{AL})$ amyloidosis diagnosed in patients with previous diagnosis of multiple myeloma. Mayo Clin Proc. 2010; 85(3): 232-238, doi: 10.4065/mcp.2009.0547, indexed in Pubmed: 20194151.

21. Dmoszyńska A, Usnarska-Zubkiewicz L, Walewski J, et al. Zalecenia Polskiej Grupy Szpiczakowej dotyczące rozpoznawania i leczenia szpiczaka plazmocytowego oraz innych dyskrazji plazmocytowych na rok 2017. Acta Haematol Pol. 2017; 48(2): 55-103, doi: 10.1016/j.achaem.2017.05.003.

22. Landgren O, Kyle RA, Pfeiffer RM, et al. Monoclonal gammopathy of undetermined significance (MGUS) consistently prece- 
des multiple myeloma: a prospective study. Blood. 2009; 113(22): 5412-5417, doi: 10.1182/blood-2008-12-194241, indexed in Pubmed: 19179464.

23. Guan J, Mishra S, Falk RH, et al. Current perspectives on cardiac amyloidosis. Am J Physiol Heart Circ Physiol. 2012; 302(3): H544-H552, doi: 10.1152/ajpheart.00815.2011, indexed in Pubmed: 22058156.

24. Röcken C, Peters B, Juenemann G, et al. Atrial amyloidosis: an arrhythmogenic substrate for persistent atrial fibrillation. Circulation. 2002; 106(16): 2091-2097, indexed in Pubmed: 12379579.

25. Rapezzi C, Merlini G, Quarta CC, et al. Systemic cardiac amyloidoses: disease profiles and clinical courses of the 3 main types.
Circulation. 2009; 120(13): 1203-1212, doi: 10.1161/CIRCULATIONAHA.108.843334, indexed in Pubmed: 19752327.

26. Pearson G, Robinson F, Beers Gibson T, et al. Mitogen-activated protein (MAP) kinase pathways: regulation and physiological functions. Endocr Rev. 2001; 22(2): 153-183, doi: 10.1210/ /edrv.22.2.0428, indexed in Pubmed: 11294822.

27. Carlomagno F, Anaganti S, Guida T, et al. BAY 43-9006 inhibition of oncogenic RET mutants. J Natl Cancer Inst. 2006; 98(5): 326-334, doi: 10.1093/jnci/djj069, indexed in Pubmed: 16507829.

28. Keating GM, Santoro A. Sorafenib: a review of its use in advanced hepatocellular carcinoma. Drugs. 2009; 69(2): 223-240, doi: 10.2165/00003495-200969020-00006, indexed in Pubmed: 19228077 . 